\title{
PENGARUH PENAMBAHAN RUMPUT LAUT (Eucheuma cottonii) TERHADAP KUALITAS SENSORIK DAN PROKSIMAT PUDING
}

\author{
The Effect of Seaweed (Eucheuma cottonii) Addition on Sensoric Quality and Chemical Analysis of Pudding
}

\author{
Ahmad Syafar ${ }^{1}$, Haslianti ${ }^{1}$, Nur Asyik $^{2}$ \\ 1Jurusan Teknologi Hasil Perikanan, Fakultas Perikanan dan Ilmu Kelautan Universitas Halu Oleo, Kendari, \\ Sulawesi Tenggara, Indonesia \\ 2Jurusan IImu dan Teknologi Pangan, Fakultas Pertanian Universitas Halu Oleo, Kendari, Sulawesi Tenggara, \\ Indonesia \\ *Email korespondensi: ahmadsyafar23@gmail.com (Telp: +6282346053995) \\ Diterima: 30 September/ Disetujui 25 Oktober 2019
}

Cara sitasi: Syafar A, Haslianti, Nur Asyik. 2019. Pengaruh penambahan rumput laut (Eucheuma cottonii) terhadap kualitas sensorik dan proksimat puding. Jurnal Fish Protech. 2(2):244-250.

\section{ABSTRACT}

The aims of this study are to determine the effect of seaweed (Eucheuma cottonii) and mackerel scad fish (Decapterus spp.) ratio for the organoleptic, physical and chemical test of crackers. This study used a Completely Randomized Design (CRD) which four treatments P1 (FM 20\%: S 5\%: TF 75\%), P2 (FM 15\%: S 10\%: TF 75\%), P3 (FM 10\%: S 15\%: TF 75\%) and P4 (FM 5\%: S 20\%: TF 75\%) with three times replications. Observation data were analyzed using ANOVA (Analysis of Variance) at the level of $95 \%$, if there were significant differences $(P>0.05)$ then further testing was carried out by DMRT (Duncan Multiple Range Test) at 95\% significance level. The result showed that seaweed and mackerel scad meat ratio had a significant effect on sensory values (aroma, taste, and crispness). The best results for the sensory test were found in P1 where the taste and aroma value was 7.8 and 7.7, while the best result for texture, crispness, and appearance are 7.2, 4.3 and 7.3 was found in P4. The chemical test on crackers for protein, water content and crude fibre was $6,97 \%-11,50 \%, 3,80 \%-4,96 \%$ and $1,81-4,44 \%$ respectively. The physical test of the rising volume shows that $P 4$ had the highest value with $92 \%$.

Keywords: Chemical test, Puding, Sea weed (Eucheuma cottonii), sensory

\section{ABSTRAK}

Tujuan penelitian ini adalah untuk mengetahui pengaruh penambahan rumput laut terhadap uji sensorik dan uji kimia puding rumput laut (E. cottonii). Penelitian menggunakan Rancangan Acak Lengkap (RAL) yang terdiri dari 4 perlakuan yaitu : $P_{1}=$ rumput laut $100 \mathrm{~g}, P_{2}=$ rumput laut $125 \mathrm{~g}, P_{3}=$ rumput laut $150 \mathrm{~g}, P_{4}=$ rumput laut $200 \mathrm{~g}$ dan ulangan sebanyak tiga kali. Data hasil pengamatan dianalisa menggunakan ANOVA (Analysis of Variance) pada taraf $95 \%$, apabila terdapat berpengaruh nyata $(\mathrm{P}>0,05)$ maka dilakukan uji lanjut dengan uji DMRT (Duncan Multiple Range Test) pada taraf nyata $95 \%$. Hasil penelitian menunjukkan pengaruh sangat nyata terhadap nilai sensori meliputi warna dan tekstur sedangkan rasa berpengaruh sangat nyata namun diperoleh pengaruh tidak nyata pada aroma. Hasil terbaik untuk penilaian sensori terdapat pada perlakuan P4 yaitu dimana memiliki nilai rasa 4,26, tekstur 5,49, aroma 4,4, dan rasa 4,5. Hasil penelitian menunjukkan kadar air antara $74,24 \%-68,49 \%$, kadar abu 3,44\%-3,30\%, dan kadar protein 0,108\%$0,133 \%$.

Kata kunci: Puding, Rumput laut (Eucheuma cottonii), sensori, Uji kimia

\section{PENDAHULUAN}

Rumput laut (Eucheuma cottonii) merupakan bahan pangan lokal yang mempunyai ketersediaan yang sangat tinggi di Indonesia. Pengembangan dan pembudidayaan rumput laut di Sulawesi Tenggara 
cukup berkembang karena didukung oleh potensi sumber daya pesisir yang cukup baik untuk pengembangan rumput laut. Produksi perikanan budidaya rumput laut menurun dari 917.363 ton tahun 2013 menjadi 956.017 ton pada tahun 2014, dan penurunan produksi lebih tinggi terjadi pada tahun 2015 yakni hanya mencapai 915.895 ton (BPS, 2016).

Pemanfaatan rumput laut masih sangat rendah karena sampai saat ini mayoritas masyarakat hanya memanfaatkannya dalam bentuk rumput laut kering. Rumput laut akan memiliki nilai jual lebih tinggi jika diolah menjadi produk agar-agar, karaginan, dan alginat serta produk pangan siap konsumsi (DKP, 2006). Berdasarkan hal tersebut, maka perlu adanya pengembangan produk berbasis rumput laut. Salah satu produk olahan yang dapat meningkatkan nilai tambah rumput laut adalah puding rumput laut.

\section{METODE PENELITIAN}

\section{Alat dan Bahan}

Alat yang digunakan dalam penelitian ini ada dua macam yaitu alat untuk pengolahan dan alat untuk

\section{Rancangan Penelitian}

Penelitian menggunakan Rancangan Acak lengkap (RAL) yang terdiri dari 1 yang perlakuan. Setiap analisis. Alat pengolahan meliputi: baskom (planet), pisau (stainless steel), talenan (nampang segi), gelas ukur (herma), blender (Miyako), stopwatch, cetakan (stainless steel), thermometer (torbalscale), panci, dan kompor gas (TOP). Alat untuk analisis kimia meliputi: tabung reaksi, cawan porselin (haldenwanger), vortex (Thermo Maxi), timbangan analitik (torbalscale), hotplate, gelas piala, batang pengaduk, pipet tetes, pipet mikro (toppette P20), oven (memmert), desikator (normax), corong, tabung reaksi, labu takar, erlenmeyer (iwaki), kjedhal, tanur (Furnace D550), bunsen dan alat destilasi.

Bahan baku yang digunakan pada penelitian ini adalah rumput rumput laut (E. cottonii) dari perairan Buton Tengah yang diperoleh dari nelayan desa Balo Bone. Cucian beras, dan air hujan, akuades, Nammonia-kloroform, larutan Besi (III) klorida $1 \%$, $\mathrm{K}_{2} \mathrm{SO}_{4}$, asam sulfat, $\mathrm{H}_{2} \mathrm{SO}_{4} 15 \%, \mathrm{NaOH}, \mathrm{Na}_{2} \mathrm{~S}_{2} \mathrm{O}_{3}, \mathrm{NH}_{3}$, alkohol, $\mathrm{FeCl}_{3} \mathrm{0}, 1 \%, \mathrm{HCl}, \mathrm{HgO}, \mathrm{H}_{3} \mathrm{BO}_{3}$, Etanol, $\mathrm{Na}$ thiosulfat $0,1 \mathrm{~N}$ dan minyak zaitun

perlakuan diulang sebanyak 3 kali, jumlah satuan pada percobaan penelitian ini adalah 12 unit percobaan, dapat dilihat pada Tabel 1.

Tabel 1. Formasih bahan tambahan puding rumput laut

\begin{tabular}{lllllll}
\hline No & $\begin{array}{l}\text { Bahan } \\
\text { Rumput Laut }\end{array}$ & Agar-agar & Susu & Gula & Santan kelapa & Air \\
\hline P1 & $100 \mathrm{~g}$ & $3 \mathrm{~g}$ & $120 \mathrm{~g}$ & $25 \mathrm{~g}$ & $250 \mathrm{ml}$ & $150 \mathrm{ml}$ \\
P2 & $125 \mathrm{~g}$ & $3 \mathrm{~g}$ & $120 \mathrm{~g}$ & $25 \mathrm{~g}$ & $250 \mathrm{ml}$ & $150 \mathrm{ml}$ \\
P3 & $150 \mathrm{~g}$ & $3 \mathrm{~g}$ & $120 \mathrm{~g}$ & $25 \mathrm{~g}$ & $250 \mathrm{ml}$ & $150 \mathrm{ml}$ \\
P4 & $200 \mathrm{~g}$ & $3 \mathrm{~g}$ & $120 \mathrm{~g}$ & $25 \mathrm{~g}$ & $250 \mathrm{ml}$ & $150 \mathrm{ml}$ \\
\hline
\end{tabular}

Uji yang akan dilakukan pada penelitian ini meliputi uji sensori dan uji kimia. (Mariana, 2010) yang telah dimodifikasi). Uji sensori yang digunakan dalam penelitian ini adalah uji kesukaan (hedonik) terhadap respon produk yang diuji dengan skala hedonik yang ditransformasikan ke skala numerik. Panelis yang digunakan sebanyak 25 orang dan respon yang diuji meliputi warna, aroma, rasa, tekstur. Uji kimia yang dilakukan meliputi kadar air (SNI 1992) dan (AOAC, 1995).

\section{Analisis Data}

Data yang diperoleh dianalisis menggunakan analisis of varians (ANOVA), jika hasil analisis menunjukan beda nyata maka dilakukan uji Duncan's Multiple Range Test (DMRT) untuk mengetahui beda 
nyata antar perlakuan dengan tingkat kepercayaan

$95 \%(\alpha=0,05)$.

\section{HASIL DAN PEMBAHASAN}

Tabel 2. Rekapitulasi analisis fitokimia rumput laut (E. cottonii)

\begin{tabular}{|c|c|c|c|}
\hline No. & $\begin{array}{l}\text { Uji } \\
\text { Fitokimia }\end{array}$ & $\begin{array}{l}\text { Hasil } \\
\text { Uji }\end{array}$ & $\begin{array}{l}\text { Hasil Uji Positif } \\
\text { (Harbone, 1987) }\end{array}$ \\
\hline 1 & Alkaloid & + & Endapan Merah \\
\hline 2 & Saponin & + & Terbentuk Buih \\
\hline 3 & Tanin & - & $\begin{array}{l}\text { Berwarna merah / } \\
\text { biru tua / hijau } \\
\text { kehitaman }\end{array}$ \\
\hline 4 & Fenol & - & $\begin{array}{l}\text { Berwarna } \\
\text { hijau/hijau } \\
\text { biru } \\
\text { kehitaman }\end{array}$ \\
\hline
\end{tabular}

Keterangan: $\quad+=$ terdapat senyawa

- = tidak terdapat senyawa

Hasil uji fitokimia terhadap kandungan alkaloid dengan pereaksi dragendorf didapatkan adanya alkaloid dalam rumput laut (E. cottonii) ditandai dengan perubahan larutan yang terbentuknya

\section{Uji fitokimia rumput laut (E. cottonii)}

endapan merah. Penelitian ini sesuai dengan penelitian Yanuarti (2017) yaitu adanya senyawa alkaloid pada rumput laut (E. cottonii). Hal ini disebabkan terjadinya reaksi antara atom nitrogen pada senyawa alkaloid dengan logam yang terkandung dalam pereaksi-pereaksi tersebut membentuk senyawa kompleks.

Hasil uji fitokimia terhadap kandungan saponin dengan uji busa didapatkan adanya saponin dalam rumput laut (E. cottonii) yaitu ditandai dengan perubahan larutan yang terbentuknya buih. Penelitian ini sesuai dengan penelitian Podungge et al. (2018) yaitu adanya senyawa saponin pada rumput laut. Hal ini karena penambahan kolesterol saat penlitian, menurut Robinson (1995) untuk memurnikan banyak saponin dengan menambahkan kolesterol yang menyebabkan pembentukan senyawa kompleks adisi yang tidak larut dalam air

\section{Uji Sensori}

Berdasarkan hasil uji sensori puding rumput rumput laut (E. cottonii) disajikan pada Tabel 3.

Tabel 3. Rekapitulasi analisis uji sensori puding rumput laut (E. cottonii)

\begin{tabular}{ccccc}
\hline Perlakuan & Warna \pm SD & Tekstur \pm SD & Aroma \pm SD & Rasa \pm SD \\
\hline P1 & $4,46^{\mathrm{d}} \pm 0,1$ & $4,11^{\mathrm{a}} \pm 0,1$ & $4,4 \pm 0,1$ & $4,19^{\mathrm{a}} \pm 0,1$ \\
P2 & $4,26^{\mathrm{bc}} \pm 0,1$ & $5.25^{\mathrm{b}} \pm 0,2$ & $4,3 \pm 0,2$ & $4,3^{\mathrm{b}} \pm 0,1$ \\
P3 & $4,14^{\mathrm{a}} \pm 0,1$ & $5,27^{\mathrm{bc}} \pm 0,1$ & $4,3 \pm 0,1$ & $4,4^{\mathrm{bc}} \pm 0,2$ \\
P4 & $4,27^{\mathrm{b}} \pm 0,1$ & $5,49^{\mathrm{bcd}} \pm 0,2$ & $4,2 \pm 0,1$ & $4,5^{\mathrm{cd}} \pm 0,2$
\end{tabular}

Keterangan : Angka-angka yang diikuti dengan notasi huruf yang sama menunjukkan berbeda tidak nyata berdasarkan uji DMRT 0.05 taraf kepercayaan $95 \%$, SD : standar deviasi

\section{Warna}

Nilai rerata analisis uji sensori terhadap warna berkisar antara 4,14 sampai 4,46 (Tabel 3). Nilai warna puding rumput laut tertinggi terdapat pada perlakuan $\mathrm{P} 1$, hal ini diduga tingginya nilai warna puding rumput laut disebabkan adanya penambahan rumput laut, semakin banyak penambahan rumput laut maka warna puding menjadi warna putih kecoklatan. Hal tersebut sesuai dengan pernyataan Roslita et al., (2018). Hal ini disebabkan perbedaan jumlah komposisi bahan rumput laut yang digunakan sehingga mempengaruhi warna puding, semakin banyak jumlah rumput laut $E$. cottonii, yang digunakan puding semakin berwarna agak kecoklatan.

Nilai terendah terletak pada perlakuan P3. karena warna dari rumput laut kurang spesifik memberikan warna khas rumput laut terhadap puding. Hal tersebut sesuai dengan pernyataan Safitri et al. (2018). Hal ini diduga karena proporsi pemberian rumput laut yang berbeda kurang mempengaruhi nilai 
warna produk puding. Hal ini disebapkan karena warna dari rumput laut kurang spesifik memberikan warna khas terhadap puding. Warna dari puding ini sendri tidak terlalu terang dikarenakan pada proses pemanasan rumput laut memudar sehingga lebih dominan warna puding putih. Dengan kata lain, pembentukan warna dari puding berasal dari kombinasi bahan-bahan penyusun puding dimana rata-rata bahan tersebut memiliki warna putih sehingga menghasilkan warna puding yang putih cerah.

\section{Tekstur}

Nilai rerata analisis uji sensori terhadap tekstur berkisar antara 4,11 sampai 5,49 (Tabel 3). Nilai tekstur puding rumput laut dengan nilai tertinggi terletak pada perlakuan P4 hal ini diduga tingginya nilai tektur puding rumput laut disebapkan puding memiliki tekstur lembut dan kenyal. Hal tersebut sesuai dengan pernyataan Campo (2009). Hal ini disebabkan karena asam dapat meningkatkan kekuatan karaginan rumput laut untuk meningkatkan pembentukan gel. Dalam pembuatan puding, karaginan berfungsi untuk mengontrol viskositas dan tekstur puding. Menurut Khordi (2010), produk gel yang disimpan pada suhu rendah seperti puding dan jeli memerlukan sifat kekuatan gel tinggi dan sineresis rendah. Sineresis yang tinggi pada produk gel akan menyebabkan gel menjadi mengkerut atau kering selama penyimpanan. Tektur merupakan sensasi tekanan yang dapat di amati dengan mulut (pada waktu di gigit, dikunyah dan ditelan) atau pun perabaan dengan jari (Sari et al. 2013).

Nilai terendah yaitu terletak pada perlakuan P1 hal ini diduga ada rumput laut yang tekstur lembut dan tidak kenyal. Menurut Khordi (2010), produk gel yang disimpan pada suhu rendah seperti puding dan jeli memerlukan sifat kekuatan gel tinggi dan sineresis rendah. Sineresis yang tinggi pada produk gel akan menyebabkan gel menjadi mengkerut atau kering selama penyimpanan. Hal ini diduga karena panelis tidak dapat mendeteksi adanya perbedaan tekstur antar perlakuan walaupun secara uji kekuatan gel terlihat berbeda sangat nyata.

\section{Aroma}

Nilai rerata analisis uji sensori terhadap aroma berkisar antara 4,2 sampai 4,4 (Tabel 3). Nilai aroma puding rumput laut dengan nilai perlakuan yang tertinggi pada perlakuan P1 dengan niali 4,4 diduga aroma yang dihasilkan dari puding adalah aroma khas rumput laut. Hal tersebut sesuai dengan pernyataan Dewi et al., (2010) tingginya nilai kesukaan panelis pada perlakuan $\mathrm{P} 1$ diduga karena proporsi rumput laut signifikan mempengaruhi nilai sensorik produk puding. Hasil tersebut membuktikan aroma puding yang dihasilkan secara umum masih kuat aroma spesifik rumput laut (E. cottonii).

Nilai terndah yaitu terletak pada perlakuan P4 dengan nilai 4,2. Hal ini disebabkan kura terciumnya aroma rumput laut terhadap puding, hal ini sesuai dengan penilitian. Dewi et al (2010) tentang pengolahan puding dari rumput laut E.cottonii kesukaan terhadap aroma disebabkan karena aroma dari rumput laut, dimana $E$. cottonii memiliki aroma spesifik rumput laut. Hasil uji sensorik aroma pada penilitian ini hampir sesuai dengan nilai rerata aroma pada penelitian Fransiska et al (2014) 4,27 sampai 4,60 .

\section{Rasa}

Nilai rerata analisis uji sensori terhadap rasa berkisar antara 4,19 sampai 4,5 (Tabel 3). Nilai tertinggi pada perlakuan P4 dengan nilai 4,5 diduga karna hasil rasa perlakuan P4 merupakan perlakuan yang tertinggi disukai panelis. Hal tersebut sesuai dengan pernyataan Winarno, (2013). Hal ini disebabkan perbedaan angka ini terjadi karena penggunaan rumput laut yang berbeda pada setiap perlakuan dalam produk puding.

Nilai terendah pada perlakuan $\mathrm{P} 1$ dengan nilai 4,19. Hal ini di sebabkan Hasil rasa perlakuan P1 merupakan perlakuan yang rendah disukai panelis dikarenakan kurangnya rasa rumput laut yang terdapat pada produk puding. Hal tersebut sesuai

dengan pernyataan Desrosier, (1988), hal ini diduga menunjukkan bahwa banyak panelis yang tidak menyukai rasa yang ditimbulkan dari produk ini, 
disebabkan rasa amis yang berasal dari bahan alami puding yaitu rasa amis dari rumput laut. Rasa amis bisa diminimalisir bahkan dihilangkan dengan adanya perendaman Air cucian beras mengandung asam asetat ketika terjadi proses fermentasi. Dalam proses perendaman terjadi fermentasi aerob (proses fermentasi dengan udara) karbohidrat akan diubah menjadi gula oleh Saccharomyces cerevisiae, gula diubah menjadi alkohol, alkohol akan diubah oleh Acetobacter aceti menjadi asam asetat. Hasil uji sensorik rasa pada penilitian ini hampir sesuai dengan nilai rerata rasa pada penelitian Fransiska et al (2014) 2,87 sampai 4,13.

\section{Uji Kimia Puding}

Hasil pengujian analisis kandungan kadar air, abu dan protein disajikan pada Tabel 4.

Tabel 4. Hasil uji kimia terhadap kandungan kadar air, abu dan protein puding rumput laut $(E$. cottonii).

\begin{tabular}{llccc}
\hline No & Kode & \multicolumn{3}{c}{ Hasil Uji } \\
\cline { 3 - 5 } & Sampel & $\begin{array}{c}\text { Kadar } \\
\text { air (\%) }\end{array}$ & $\begin{array}{c}\text { Kadar } \\
\text { air (\%) }\end{array}$ & $\begin{array}{c}\text { Kadar } \\
\text { protein } \\
(\%)\end{array}$ \\
\hline 1 & P1U2 & 68,49 & 3,43 & 0,133 \\
2 & P2U1 & 70,36 & 3,37 & 0,108 \\
3 & P3U1 & 69,71 & 3,44 & 0,121 \\
4 & P4U3 & 74,24 & 3,30 & 0,133 \\
\hline
\end{tabular}

\section{Kadar Air}

Nilai rerata hasil uji kadar air puding dengan penambahan rumput laut ( $E$. cottonii) dengan nilai indeks efektifitas, diketahui bahwa kadar air puding tertinggi terdapat pada perlakuan P4 yaitu $74,24 \%$ dan terendah terdapat pada perlakuan P1 yaitu $68,49 \%$ (Tabel 4) . Nilai tertinggi penelitian ini lebih tinggi dari penelitian pudding dengan hasil terbaik penelitian Oktari et al (2013) yaitu 23,51\%

Tingginya nilai kadar air puding rumput laut disebabkan karena kadar air puding ditentukan oleh kadar air bahan tambahan rumput laut. Hasil tersebut sesuai dengan pernyataan Jumri et al. (2012) kadar air suatu produk ditentukan oleh kadar air bahan baku, bahan pengikat yang digunakan dan proses pemasakan. Rahmi et al. (2012) menyatakan bahwa substansi pada bahan terlalu banyak mengandung air atau padatan terlarutnya terlalu rendah sehingga konsistensinya tidak begitu kuat.

Rendahnya kadar air pada perlakuan P1 diduga karena lama penyimpanan puding mengikuti sifat rumput laut yang cepat mengalami penurunan kadar air. Menurut Santosa et al (2016) bahwa kadar air rumput laut mengalami penurunan atau kehilangan air perjam. Hal ini disebabkan pada awal pengeringan rumput laut menguap air bebas terlebih dahulu, kemudian mengeluarkan air yang terikat secra fisik hal tersebut sesuai pendapat hendrson dan perry (1982) dalam Santosa et al (2016) yang menyatakan bahwa massa air yang tersedia dalam jumlah yang besar dipermukaan bahan menyebabkan penuruanan kadar air yang tersedia dalam jumlah yang besar dipermukaan bahan menyebabkan penurunan kadar air saat masa air semakin mendekati keseimbangan. Penurunan kadar air dipengaruhi oleh energi aktivasi yang di butuhkan untuk pengeringan dan juga di pengaruhi oleh suhu pengeringan semakin tinggi suhu pengeringan yang dikeluarkan dari rumput laut akan semakin banyak sehingga terjumlah air yang tersisa pada rumput laut akan semakin sedikit.

\section{Kadar Abu}

Nilai rerata hasil uji kadar abu puding dengan penambahan rumput laut ( $E$. cottonii) dengan nilai indeks efektifitas, diketahui bahwa kadar abu puding tertinggi terdapat pada perlakuan P3 yaitu 3,44 \% dan terendah terdapat pada perlakuanan P4 yaitu 3,30\% (Tabel). Nilai tertinggi penelitian ini lebih tinggi dari penelitian puding dengan hasil terbaik penelitian Sani (2014) yaitu $1,27 \%$.

Tingginya kadar abu pada perlakuan P3 diduga Tinggi penambahan rumput laut maka kadar abu puding rumput laut cenderung meningkat, hal ini disebapkan rumput laut mengandung mineral cukup tinggi. Hal ini sejalan dengan Fransiska et al (2014) yang menyatakan Alga coklat temasuk bahan yang mengandung mineral cukup tinggi seperti $\mathrm{Na}, \mathrm{Ca}, \mathrm{K}$, Cl, Mg, Fe, dan S. Winarno (1996) menyatakan bahwa 
kandungan abu pada produk menunjukkan kemurnian produk yang dipengaruhi oleh kandungan mineral bahan baku.

Rendahnya kadar abu pada perlakuan P4 diduga karena bahan tambahan pangan seperti susu pada pengolahan puding tidak mempengaruhi kadar abu dan gula dapat memberikan nilai yang signifikan. Hal ini hampir sesuai dengan penelitian Sani (2014) bahwa pada hasil analisis kadar air yaitu keberadaan jenis susu tidak mempengaruhi terhadap kadar abu namun keberadaan jenis gula dapat berpengaruh, selain itu perbedaan penambahan rumput laut yang berbada dapat menghasilkan kadar abu yang berbeda pula, sehingga kadar abu dapat menurun sesuai dengan sedikitnya rumput laut yang ditambahkan dalam pembuatan puding. Menurut Panggalih (2010) semakin rendah nilai kadar abu maka kandungan mineral pada bahan semakin sedikit

\section{Kadar Protein}

Nilai rerata hasil uji kadar protein puding dengan penambahan rumput laut (E. cottonii) dengan nilai indeks efektifitas, diketahui bahwa kadar protein puding menunjukan hasil nilai tertinggi terdapat pada perlakuan $\mathrm{P} 1$ yaitu $0,133 \%$ dan terendah terdapat pada perlakuan P2 yaitu 0,108\% (Tabel 4). Nilai tertinggi penelitian ini lebih tinggi dari penelitian puding dengan hasil terbaik penelitian Roslita et al (2018) yaitu $0,111 \%$.

Tingginya kadar protein pada perlakuan $\mathrm{P} 1$ diduga karena kandungan protein dari penambahan dan pencampuran rumput laut dan susu saat pembuatan puding. Menurut Winarno (1997) kadar protein pada tiap bahan yang dicampurkan pada setiap perlakuan, sehingga terjadi peningkatan kadar protein yang berada dari perlakuan satu dengan lainnya sesuai bahan yang digunakan. Kenaikan hal ini di pengaruhi oleh kandungan protein pada rumput laut cukup tinggi yaitu sekitaran 20-25\%. Selain itu, tingginya kadar protein pada puding di sebabkan oleh penambahan susu dalam pembuatan puding hal ini sesuai dengan pernyataan Khotimah (2006) bahwa kadar protein sampel yang berbeda di pengaruhi oleh bahan tambahan yang di gunakan selama pengolahan dan proses yang mempengaruhi Ekestabilan protein.

Rendahnya kadar protein pada perlakuan P2 diduga karena rumput laut mengalami degradasi saat pemasakaan sebelum penambahan rumput luat sehingga tidak ada bahan baku lain yang mengikat kadar protein pada puding, selain itu sifat dari kosentrat protein dari rumput laut kering yang digunakan dalam pembuatan puding yang dipengaruhi oleh adanya proses pengeringan dan pengaruh panas serta dehidrasi osmotik dapat menyebabkan denaturasi protein. Denaturasi protein oleh panas akan mengubah struktur protein dan dapat mengkerutkan bahan. Hasil tersebut sesuai dengan pernyataan Damayanthy dan Eddy (1995) bahwa proses pemanasan akan menyebabkan protein mengalami degradasi dan keadaan ini tidak hanya menyebabkan penurunan nilai gizinya tetapi aktivitas protein sebagai enzim dan hormon akan hilang.

\section{KESIMPULAN}

Berdasarkan hasil dan pembahasan, maka dapat disimpulkan sebagai berikut :

1. Terdapat perbedaan pengaruh penambahan rumput laut pada puding menunjukan sangat nyata terhadap warna dan tekstur, berpengaruh nyata terhadap rasa dan berpengaruh tidak nyata terhadap aroma. Perlakuan terbaik adalah perlakuan P4 dengan karakteristik warna 4,27(suka), tekstur 5,49 (sangat suka), aroma 4,2 (suka) dan rasa 4,5 (sangat suka).

2. Terdapat perbedaan nilai kadar kimia yang ada pada setiap perlakuan puding rumput laut. Nilai kadar air yang tertinggi pada perlakuan P4 berkisar $74,24 \%$ dan perlakuan terendah $\mathrm{P} 1$ berkisar $68,49 \%$, nilai kadar abu yang tertinggi pada perlakuan $\mathrm{P} 3$ berkisar 3,44\% dan perlakuan terendah P4 3,30\%, nilai kadar protein yang tertinggi pada perlakuan $\mathrm{P} 1$ berkisar $0,133 \%$ dan perlakuan terendah $\mathrm{P} 2 \mathrm{0,108 \%}$. 


\section{DAFTAR PUSTAKA}

BPS. 2016. Produksi Rumput Laut Menurut Kabupaten Kota Di Provinsi Ntt. Cited In Https://Ntt.Bps.Go.Id/Dynamictable/2018/02/0 9/629/Produksi-Rumput-Laut-MenurutKabupaten-Kota-Di-Provinsi-Nusa-TenggaraTimur-2011-2016. Html. [31 Juli 2018].

Buckle KA, Edward RA, Fleet GH, Wotto N. 1987. IImu Pangan. Ed ke-2. Penerjemah : Purnomo $\mathrm{H}$. Adiono. Jakarta : UI Press.

Copriyadi J, Yasmi E, Hidayati. 2005. Isolation and characterization of coumarines from peels of orange (Citrus hystrix DC). Jurnal Biogenesis. 2: $13-25$.

Damayanthi E dan Eddy. 1995. Teknologi Makanan.

Departemen Pendidikan Dan Kebudayaan.

Dikdasmen. Jakarta.

Departemen Kelautan Dan Perikanan (DKP). 2006.

Pedoman Umum Kelembagaan Tempat

Pelelangan Ikan. Direktorat Pemasaran

Dalam Negeri. Direktorat Jenderal Pengolahan Dan Pemasaran Hasil Perikanan. Jakarta: Departemen Kelautan Dan Perikanan Republik Indonesia

Dewi, Eko N, Titi S, dan Ulfatun. 2010. Jurnal Kualitas

Selai Yang Diolah Dari Rumput Laut Gracilaria verruscosa, Eucheuma cottonii serta campuran keduanya. Jurnal Perikanan. Universitas Diponegoro. Semarang.

Desrosier, N. W. 1988. Teknologi Pengawetan Pangan. Edisi III. Penerjemah Muchji Mulyohardjo. Jakarta: Universitas Indonesia.

Faridah L. 2001. Studi Tentang Pembuatan Tepung Instan Karaginan Dari Rumput Laut Kappaphycus Alvarezii. [Skripsi]. Bogor (Id): Fakultas Perikanan Dan IImu Kelautan, Ipb.

Jumri, Yusmarini, dan Netti H. 2012. Mutu Puding Buah Naga Merah (Hylocereus Polyrhizus) Dengan Penambahan Karagenan Dan Gum Arab. Jom Faperta. Vol: 2 (1).

Khordi. 2010. Penelitian Pembuatan Karaginan Dari Rumput Laut Eucheuma Cottonii Di Wilayah
Perairan Kabupaten Jeneponto Propinsi Sulawesi Selatan. Makassar:Universitas Hasanudin.

Khotima (2006) pembuatan susu bukbuk dengan foam-mat Driying : kajian pengaruh bahan penstabilan terhadap kualitas susu bubuk. Juranal protein. Jurusan peternakan. Fakultas peternakan - perikanan. Universitas Muhamadia Malang

Oktari A., Ira S. dan Dewita. 2017. Pengaruh Penambahan Sari Pati Pandan (Pandanus Amaryllifolius) pada Pembuatan Puding Karaginan. [Jurnal] Vol. 5. Bidang Perikanan dan IImu Kelautan. Universitas Riau.

Rahmi, Tafzi F., dan Anggraini S. 2012. Pengaruh Penambahan Gelatin Terhadap Pembuatan puding Dari Bunga Rosella (Hibiscus Sabdariffa Linn). Jurnal Penelitian Universitas Jambi Seri Sains. 14 (1): 37-44

Rosalita, Syam, H., Fadhilah R., 2018. terhadap kualitas organoleptik puding rumput laut (eucheuma cottonii) Jurnal Pendidikan Teknologi Pertanian Volume 4 September Suplemen (2018) : S92- S103 p-ISSN : 24768995 e-ISSN : 2614-785.

Sani. 2014. Pengembangan Puding Instan Tinggi Fe Sebagai Makanan Selingan Untuk Remaja Putri. [Skripsi]. Departemen Gizi Masyarakat. Fakultas Ekologi Manusia. Institut Pertanian Bogor. Bogor

Santosa, G.W. 2003. Budidaya Rumput Laut. Program

Community College Industri Kelautan dan Perikanan. Universitas Diponegoro. Semarang.

Winarno, 2008. Kimia pangan dan gizi. Bogor. M-Brioo Press. Jakarta.

Winarno, F.G. (1996). Teknologi Pengolahan Rumput Laut. Pustaka Sinar Harapan, Jakarta. 103 p. Winarno, F.G.2002. kimia pangan dan gizi. Jakarta : PT Gramedia Pustaka Utama.

Winarno Fg. 1997. Kimia Pangan Dan Gizi. Gramedia. Jakarta (Id) 